\title{
QUANTIFYING CONCENTRATED AND DIFFUSE RECHARGE IN TWO MARBLE KARST AQUIFERS: BIG SPRING AND TUFA SPRING, SEQUOIA AND KINGS CANYON NATIONAL PARKS, CALIFORNIA, USA
}

\author{
Benjamin W. Tobin* and Benjamin F. Schwartz \\ Texas State University - San Marcos, Department of Biology, 601 University Drive, San Marcos, TX 78666
}

\begin{abstract}
To improve water management in mountain systems, it is essential that we understand how water moves through them. Researchers have documented the importance of porous-media aquifers in mountain river systems, but no previous research has explicitly included mountain karst as part of conceptual models. To do so, we used discharge and geochemical parameters measured along upstreamto-downstream transects under high- and low-flow conditions in 2010 to assess storage characteristics and geochemical properties of two mountain marble-karst systems, the Big Spring and Tufa Spring systems in Sequoia and Kings Canyon National Parks, California. During both high- and low-flow conditions, we quantified the relative contributions of concentrated and diffuse recharge in both karst systems, and we used a simple linear mixing model to calculate specific conductance in unsampled diffuse sources that ranged from $34 \mu \mathrm{S} \mathrm{cm}{ }^{-1}$ to $257 \mu \mathrm{S} \mathrm{cm}^{-1}$. Data show that the Big Spring system has a much higher seasonal storage capacity than the Tufa Spring system, and that diffuse sources dominate discharge and geochemistry under baseflow conditions in both aquifer systems. Baseflow in Big Spring was $0.114 \mathrm{~m}^{3} \mathrm{~s}^{-1}$ and in Tufa Spring it was $0.022 \mathrm{~m}^{3} \mathrm{~s}^{-1}$. Snowmelt-derived allogenic recharge dominates both systems during high discharge periods, measured at Big Spring as $0.182 \mathrm{~m}^{3} \mathrm{~s}^{-1}$ and Tufa Spring as $0.220 \mathrm{~m}^{3} \mathrm{~s}^{-1}$. A conceptual model is proposed that explicitly includes the effects of karst aquifers on mountain hydrology when karst is present in the basin.
\end{abstract}

\section{INTRODUCTION}

Understanding how water enters and is stored in karst aquifers is essential to characterizing storage properties, as well as assessing the vulnerability of an aquifer to contamination (Scanlon et al., 2003). In mountain aquifer systems, little is known about storage and vulnerability relative to our understanding of larger aquifers that are more intensively used and studied. For example, the Edwards Aquifer in central Texas is intensively utilized for municipal and agricultural water, and many studies have been performed to assess its storage properties and vulnerability (Scanlon et al., 2003; Musgrove and Banner, 2004; Slade et al., 1986). In mountain aquifers, however, an individual aquifer is rarely utilized directly, and it is often relatively small and difficult to access for study. Despite this, the combined effects of many small mountain aquifer systems can be important because they contribute significant amounts of water to mountain river systems (Clow et al., 2003) that may be heavily or entirely exploited for municipal, agricultural, and industrial uses as they leave the mountain range. In most cases, although small mountain aquifers can be vitally important to the surface water system, especially during dry seasons after snowmelt, they are not well characterized or studied because snowmelt dominates annual discharge. As a result, little is known about how storage varies spatially along an elevational gradient, as a function of rock type or other geologic materials, or how vulnerable these smaller aquifers are to contamination and climate change.

Clow et al. (2003) built a conceptual model of groundwater systems in mountain ranges that describes their importance in storing water and influencing biogeochemical processes. They found that aquifers in unconsolidated porous media in the Colorado Rockies, USA, play a significant role in storing water over seasonal timescales. Although they were able to quantify the roles these aquifers play in contributing to the stream systems, the systems they focused on did not include karst aquifers. Karst aquifers are often conceptualized as a network of conduits that are surrounded by and connected to a matrix, each having its own continuum of properties (Bakalowicz, 2005). To better understand storage properties and potential flow paths in a karst aquifer, it is important to quantify how the conduit and matrix components, as well as any associated porous media such as soils and glacial sediments, contribute to controlling discharge and geochemistry at a spring. The relative importance of each of these components depends on a variety of geological variables, such as matrix

*Corresponding author: bt1171@txstate.edu 
porosity, fracture frequency and aperture, epikarst thickness, soil thickness, and phreatic storage, that ultimately affect both water storage and contaminant movement in an aquifer (Ford and Williams, 2007).
In the Sierra Nevada in Sequoia and Kings Canyon National Parks (SEKI), California (Fig. 1), karst aquifers, formed in numerous long and narrow bands of marble in the Kaweah River basin, contribute substantially to

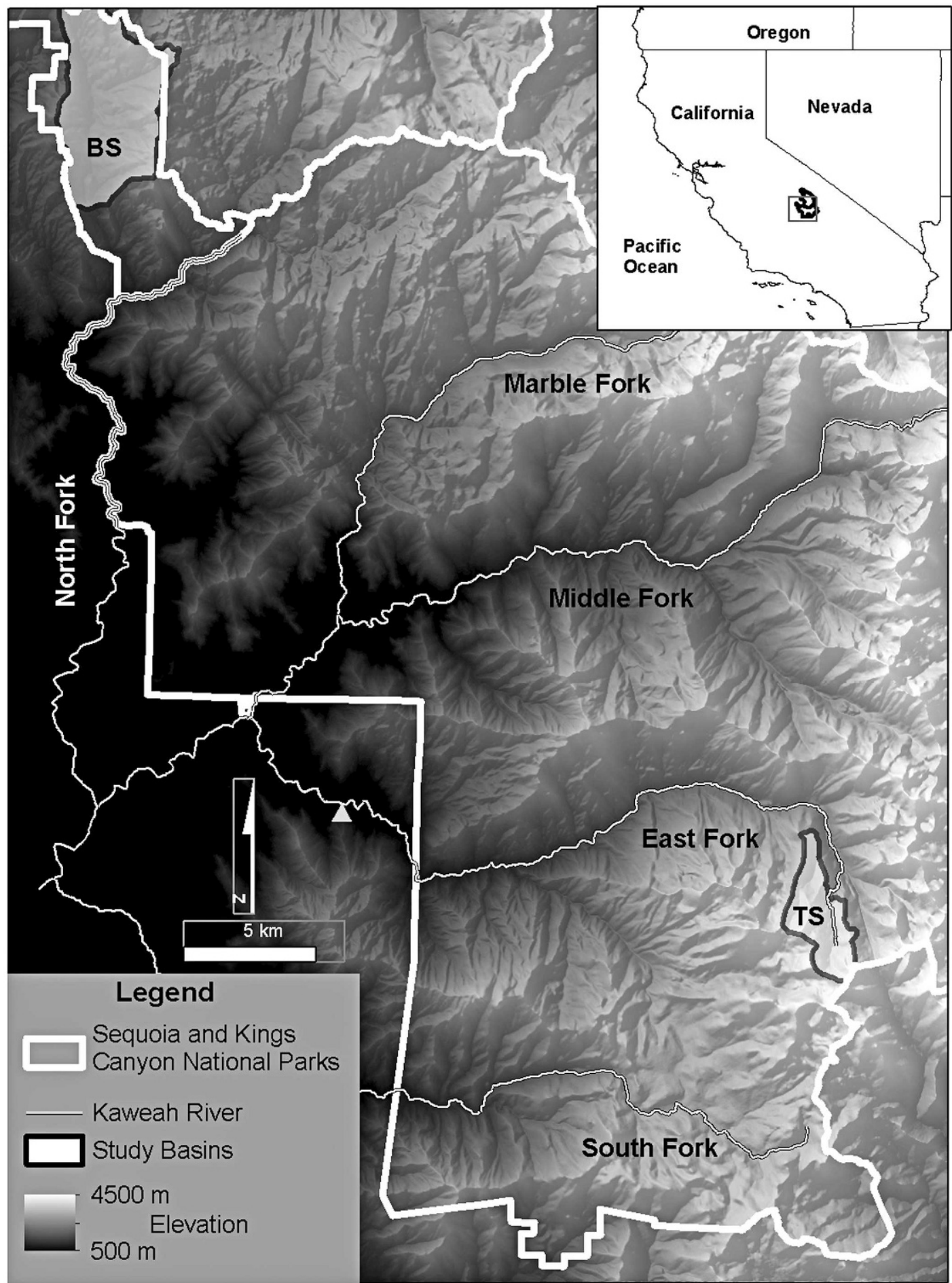

Figure 1. Drainage basin locations. Inset map shows Sequoia and Kings Canyon National Parks and the study location (rectangle) in the state of California, USA. Groundwater systems studied are noted by letters BS for Big Spring and TS for Tufa Spring. USGS gauging site 11208731, on the East Fork, is noted by a gray triangle. 
maintaining river flows during the dry season (Despain, 2006; Tobin and Doctor, 2009). However, with only a few exceptions, even the most basic quantitative data describing how, how much, where, and when water enters and moves through these groundwater systems, and what their geochemical properties are, is nonexistent.

Six of the karst aquifers in the Kaweah River basin provide the only known habitat for two endemic aquatic species, an isopod (Bomanecellus sequoia) and an undescribed flatworm. Recent applications of fire-retardants in one of these watersheds highlighted the need for at least a basic understanding of how the systems function before management strategies can be implemented. However, to develop realistic and effective management strategies for both the surface and subsurface systems associated with these and other aquifers in SEKI, resource managers first require the development of conceptual models that describe how water and mobilized contaminants move through the aquifer systems.

Flow dynamics and pollutant type have been shown to play major roles in determining the overall impact a contaminant has on a karst ecosystem. For example, Loop and White (2001) documented that if contaminants enter the karst system via concentrated recharge, they remain primarily in the conduit systems. Conversely, if contaminants enter a system via diffuse infiltration, they are likely to behave more similarly to contaminants in typical porous media and fractured aquifers. While SEKI karst systems contain both rapid and slow flowpaths, the systems are additionally complicated by the fact that they may include flow derived from multiple karstic sources, as well as from adjacent non-karstic groundwater sources and varying amounts and types of overlying porous media such as glacial deposit. In Indiana, Iqbal and Krothe (1995) documented multiple flow paths in a flat-lying mantled karst, where movement through overlying unconsolidated materials is typically dominated by laminar flow and transport in the karst bedrock is usually through conduits with turbulent flow. Although their study occurred in a different geologic setting, it showed that karst systems overlain by porous media may have substantial amounts of water stored in an overlying, perched aquifer, whether this is part of the epikarst or not.

SEKI receives airborne contaminants of local, national, and international origins. Significant amounts of lead, cadmium, mercury, and other heavy metals, as well as currently and previously used pesticides, have been documented in snow, lake sediment, and both wet and dry atmosphere samples collected in SEKI (Landers et al., 2010). The negative effects of these contaminants on aquatic ecosystems have been repeatedly documented (Hafner et al., 2007; Schwint et al., 2008), and research in the Kaweah River basin in SEKI has shown that pollutants deposited on the land surface are easily mobilized and transported into aquatic systems via seasonal precipitation runoff and snowmelt (Engle et al.,
2008). In certain areas, contaminants are transported into and through karst aquifers before being discharged into the larger river system (Despain and Tobin, 2010).

One of the major issues hindering our understanding of how potential contaminants enter and move through small mountain karst systems is the lack of a generalized conceptual model describing storage and flow in these systems. Consequently, there is a need for a conceptual hydrogeologic model that can be used as a foundation for additional work in SEKI and elsewhere. Clow et al. (2003) provide a starting point by describing storage and recharge in non-karstic mountain aquifer systems. Besides the lack of karst in their study system, a difference between their system and those found in the Kaweah River basin is the significantly lower quantities and thicknesses of unconsolidated glacial and landslide deposits in the Kaweah. Without extensive unconsolidated deposits, dryseason baseflow should be extremely low in the Kaweah. However, the opposite has been documented. Peterson et al. (2008) found that, relative to basin size, baseflow was higher in the Kaweah than in surrounding river basins with more substantial glacial deposits. This finding strongly suggests that different storage components must be supporting baseflow. In the Kaweah Basin, the most likely candidate is karst.

Because of their diversity and distribution across a large elevation gradient, the karstified marble aquifers in SEKI provide ideal study systems for adapting the conceptual model of mountain aquifer systems to include the effects of karst on storage, baseflow, and stream chemistry. To achieve this, we measured upstream-to-downstream variations in water quantity and chemistry in two aquifer systems, the Tufa Spring system (Fig. 2) and the Big Spring system (Fig. 3). These systems are typical of karstic systems in the Kaweah Basin in that they include narrow bands of marble bedrock that are at least partially mantled by overlying unconsolidated glacial and landslide materials. These unconsolidated deposits add another layer of complexity to storage, flow, and recharge processes already known to occur in the karstic portion of the aquifer systems. By measuring all concentrated recharge sources in both stream-aquifer systems and by measuring changes in chemistry as water moves from upstream sink-points, through multiple sections of the karst aquifer, and eventually rises at a spring, it is possible to calculate the contributions of concentrated and diffuse recharge components to spring discharge, as well as to constrain both the potential source areas and the basic geochemistry of diffuse recharge.

The primary goals of this research were to determine the source locations for and quantify amounts of water in two marble karst systems, to determine the proportions derived from diffuse karst and unconsolidated sources versus concentrated sources of recharge such as sinking streams during both high- and low-flow conditions, and to adapt 


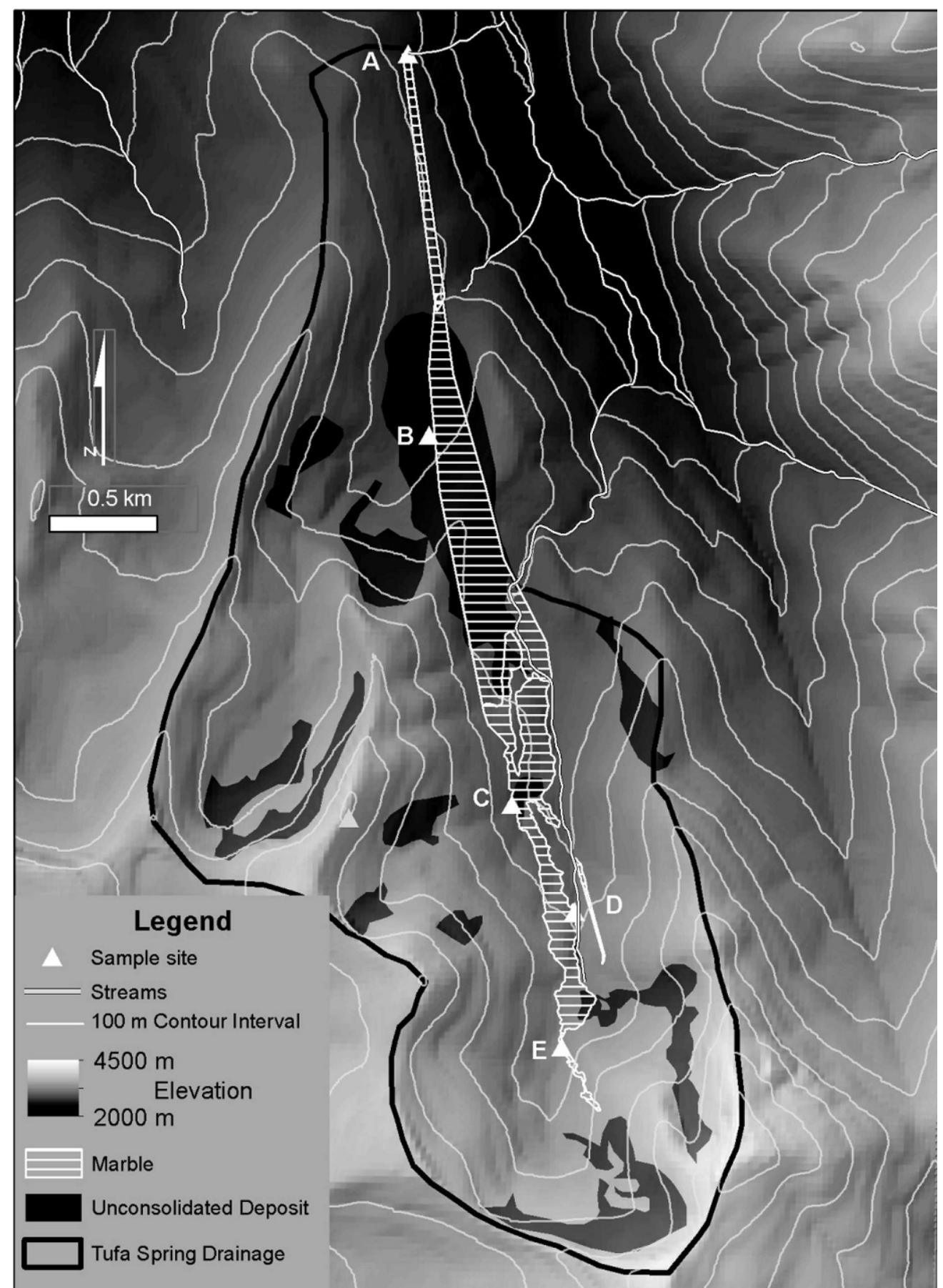

Figure 2. Tufa Spring geology showing the spatial relationship between the marble bedrock and unconsolidated deposits. Sampling locations are marked: A, Cirque Stream; B, White Chief Spring; C, White Chief Lake; D, Eagle Sink; and E, Tufa Spring, the outlet of the system.

and modify the mountain aquifer conceptual model to include the effects of karst.

Although it is a concern to resource managers in SEKI and elsewhere, this study does not specifically address the fate and transport of contaminants in mountain marble karst aquifers. Instead, this study focuses on seasonal changes in groundwater contributions from the two largest karst aquifers in the Kaweah River basin to provide insight into aquifer properties such as storage, concentrated versus diffuse sources, relative residence times, and generalized flow paths in the aquifer. In doing this, the study provides a hydrogeological and geochemical framework upon which future studies about fate and transport of contaminants, monitoring protocols, and management strategies can be built. 


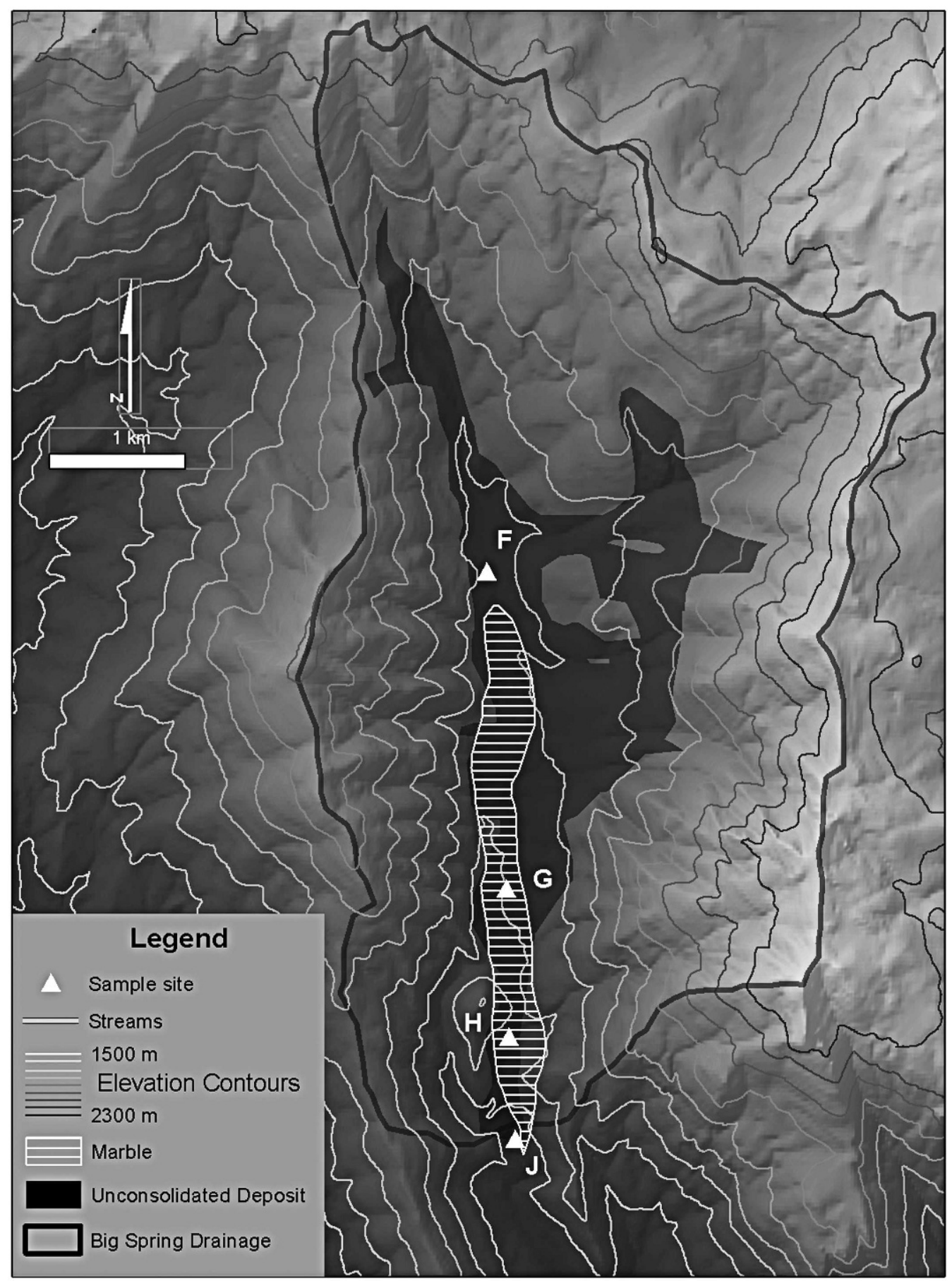

Figure 3. Big Spring geology showing the spatial relationship between the bedrock marble and unconsolidated deposits. Sampling locations are marked: F, Redwood Creek; G, White Rapids (Lilburn Cave main conduit); H, Z-Room (Lilburn Cave main conduit); and $\mathbf{J}$, Big Spring, the outlet of the system.

\section{Study Location}

SEKI, in the southern Sierra Nevada of California, contains approximately fifty documented karst aquifers, primarily in the Kaweah River basin (Fig. 1). The river basin has a catchment of $1080 \mathrm{~km}^{2}$ and ranges in elevation from approximately $300 \mathrm{~m}$ at the base of the
Sierra Nevada, to over $4,000 \mathrm{~m}$ in the upper reaches of the drainage. Spring discharge from karst aquifers is a significant source of baseflow into all forks of the Kaweah River during the dry season. Despain (2006) documented that Tufa Spring contributed approximately 30 percent of the discharge of the entire East Fork, as measured at the USGS gauging station near the 
confluence with the Middle Fork, during low-flow conditions in 2003.

The region experiences a Mediterranean climate, with most precipitation falling during winter months. Precipitation varies along an elevational gradient, with an annual average of $35 \mathrm{~cm}$ at $500 \mathrm{~m}$ elevation and $100 \mathrm{~cm}$ at $2000 \mathrm{~m}$. At elevations above $2000 \mathrm{~m}$, precipitation is primarily in the form of snow that begins melting in late spring and supplies large amounts of melt water to the river system during early summer. The wet season is followed by a long dry period through the summer months and into the fall. As snowmelt decreases throughout the summer, discharge from karst aquifers in the park supplies an increasingly larger proportion of water in the rivers (Despain, 2006).

Surface geology in the Kaweah River basin is dominated by the granite to grano-diorites of the larger Sierran Batholith (Sisson and Moore, 1994). A series of northwestsoutheast trending bands of schists, quartzites, and marbles along the western edge of the mountain range are derived from Mesozoic-aged marine sediments. The highly karstified marbles are bounded by relatively insoluble nonkarstic rocks and are excellent examples of marble-stripe karst as described by Lauritzen (2001). Unlike karst drainage basins developed in regions with extensive horizontally bedded carbonates and substantially less topographic relief, the contributing areas associated with stripe-karst aquifers have distinct boundaries. Typically, each band of marble is exposed in only one or two surface drainage basins, which constrains the areas of potential karstic and contributing drainage.

Water emerging at Tufa Spring is derived from two high-elevation basins (Despain, 2006). More than forty caves have been documented in these basins, the longest of which are White Chief Cave, with approximately $1.6 \mathrm{~km}$ of mapped passage, and Cirque Cave, with approximately $1 \mathrm{~km}$. The Big Spring system drains a larger basin in a midelevation coniferous forest and contains the longest known cave in California: Lilburn Cave, with over $32 \mathrm{~km}$ of mapped passage.

Many karst aquifers in SEKI are mantled by significant deposits of unconsolidated material such as alluvium, talus, and glacial or landslide deposits. The Big Spring and Tufa Spring aquifers are both mantled to varying degrees by these deposits. More than half of the marble that contains the Tufa Spring system is exposed in outcrops, with the remainder mantled by talus, alluvium, or glacial moraines (Fig. 2). The Big Spring system is almost entirely mantled by a series of mature landslide deposits, with only a few small surface outcrops of marble exposed in the basin (Fig. 3).

\section{Methods}

In 2010, water samples and discharge measurements were collected during high-flow (July-August) and lowflow (September-October) conditions at a series of points along the Big Spring and Tufa Spring stream-aquifer systems. Previous dye-trace studies at Tufa Spring (Despain, 2006) and Big Spring (Tinsley et al., 1981) documented the flow routes used in the analyses and discussion of this paper.

Water samples $(125 \mathrm{~mL})$ were collected from all surface streams and springs, as well as from a number of sites in caves. Sample collection and preservation in the field followed published USGS protocols (Shelton, 1994) for major cation, major anion, and nutrient analyses. Field protocol included on-site measurement of specific conductance, dissolved oxygen, $\mathrm{pH}$, and temperature. Each sample was filtered through a $0.45 \mu \mathrm{m}$ syringe filter. Samples were refrigerated and analyzed as soon as possible on Dionex ICS-1600 ion chromatographs at Texas State University to measure $\mathrm{Ca}^{2+}, \mathrm{K}^{+}, \mathrm{Mg}^{2+}, \mathrm{Na}^{+}, \mathrm{NO}_{3}^{-}, \mathrm{PO}_{4}^{3-}$, $\mathrm{SO}_{4}^{2-}, \mathrm{Cl}^{-}, \mathrm{Br}^{-}$, and $\mathrm{F}^{-}$. Alkalinity was measured by titration in the same lab using the inflection-point method (Rounds, 2006).

Discharge measurements were collected using either a pygmy meter or a turbine flow-meter (a Global Water hand-held flow meter). Springs and streams were gauged at sites having as uniform a cross-section and flow as possible, and with minimal riffles. In rocky streams, whenever possible, the most consolidated section of a stream channel having the fewest flow routes around boulders was used to minimize errors. However, due to the steep and rocky nature of nearly all stream channels and spring runs, the accuracy of discharge measurements is estimated to be $\pm 10 \%$.

In the Big Spring system, surface water samples were collected upstream of the karst system, at each known surface tributary upstream of where it recharges the karst system, and at Big Spring. Samples were collected at two locations along the main stream in Lilburn Cave (sites $G$ and $\mathrm{H}$ on Fig. 3) and at each known subsurface tributary to the main stream in the cave. Due to low flows in each surface tributary during the August sampling and no flowing water at these sampling sites in September, data from these sites could not be included in our analyses.

The Tufa Spring system is a more complex system in which water flows sequentially through a series of karst aquifers and short surface streams before finally emerging at Tufa Spring. Additionally, there are two non-karstic surface streams, White Chief Creek and Eagle Creek, flowing directly into the aquifer via sink points. Samples were collected at sinkpoints upstream of each karst segment, at each known infeeder into the system, and at each spring (Fig. 2).

To quantify the relative importance of diffuse flow to discharge at any given point along the aquifer transect, a mixing model, modified from Lackey and Krothe (1996), was used that incorporates discharge $(Q)$, and geochemical parameters: either specific conductance or ion concentration. With this method, geochemical properties can be determined for water that is added between two measured 
points in a system. In more detail, a measured geochemical parameter (specific conductance or any major ion can be used in these chemically undersaturated systems) at an upstream site $\left(C_{\mathrm{U}}\right)$ is multiplied by the flow measured at the upstream site $\left(Q_{\mathrm{U}}\right)$ and then subtracted from the geochemical parameter measured downstream $\left(C_{\mathrm{D}}\right)$ multiplied by the flow at the downstream site $\left(Q_{\mathrm{D}}\right)$. This value is then divided by the difference in measured discharge between upstream and downstream sites $\left(Q_{\mathrm{D}}-Q_{\mathrm{U}}=Q_{\text {dif }}\right)$ to calculate the geochemical parameter of interest that is added to the flow system between two measured locations. The entire expression can be written as $C_{\text {dif }}=$ $\left[\left(C_{\mathrm{D}} Q_{\mathrm{D}}\right)-\left(C_{\mathrm{U}} Q_{\mathrm{U}}\right)\right] / Q_{\text {dif }}$. Because we have measured all concentrated recharge sources, the additional water is assumed to be from diffuse sources. To calculate values for each diffuse input (1 and 2 on Fig. 4 and 3, 4, and 5 in Fig. 5), the measured values for the site(s) immediately upstream were used for the upstream values, and the site immediately downstream was used for the downstream values.

The model assumes that measured sink-point discharge values represent all concentrated recharge locations and that any additional water measured at a downstream site is from diffuse inputs. Due to the limited extent of the marble karst in the basins, we believe that we identified and quantified most, if not all, surface tributaries. Additional assumptions of the model are that minimal chemical evolution is occurring along the main flow path of the system and that additional solutes entering the system are derived from the diffuse recharge and flow components. In support of these assumptions, flow times through the aquifers are fast, with water traveling the length of the system in approximately one day (Despain, 2006; Tobin and Doctor, 2009). Additional evidences that minimal dissolution is occurring along the main conduit in both systems is that there is almost no change in the saturation

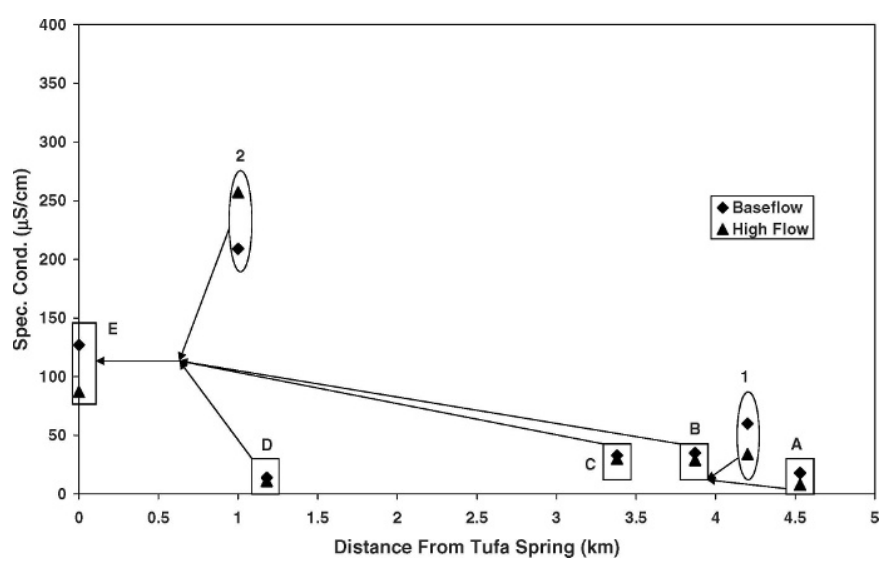

Figure 4. Downstream change in specific conductance values in the Tufa Springs system measured at surface infeeders $(A, C, D)$ and springs $(B, E)$ and calculated for diffuse inputs $(1,2)$, showing assumed mixing scenarios. Data are derived from values in Table 1.

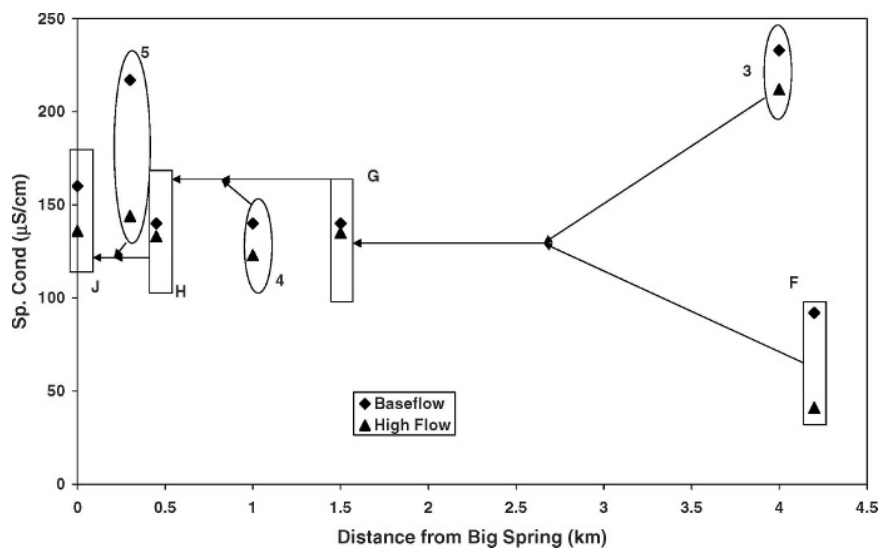

Figure 5. Downstream change in specific conductance values in the Big Spring system measured at the main surface infeeder (F), two cave stream sites $(G, H)$, and Big Spring (J) and calculated for diffuse inputs $(3,4,5)$, showing assumed mixing scenario. Data are derived from values in Table 2.

index along the main stream conduit in Lilburn Cave and there are negligible changes in measured conductivity and calcium, bicarbonate, and other ions along the main stream conduit during both sampling periods, indicating minimal dissolution along the main conduit.

\section{RESUlts AND Discussion}

Tufa and Big Springs exhibit different responses during the dry season. Tufa Spring discharge decreased by an order of magnitude, while Big Spring discharge decreased by less than $50 \%$. Tufa Spring also showed much larger differences in the proportions of discharge derived from concentrated and diffuse flow under different flow regimes. Mixing-model results show that the proportion of diffuse water in the Tufa Spring system was $41 \%$ during high flow and $68 \%$ during baseflow (Table 1). The magnitude of the change in discharge values in the system, however, suggests that, although a large portion of the discharge was derived from diffuse recharge under both conditions, the average residence time in the Tufa Spring system is relatively low. Discharge decreased from $0.22 \mathrm{~m}^{3} \mathrm{~s}^{-1}$ to $0.02 \mathrm{~m}^{3} \mathrm{~s}^{-1}$ between high flow and baseflow periods. Calculated values in the Tufa Spring system show high conductivity and ionic concentrations for diffuse input source 2 in Figure 4, between points $\mathrm{D}$ and $\mathrm{E}$ in Figure 2, which is consistent with values from other karst springs in SEKI that are dominated by diffuse contributions; small karst springs without any known concentrated recharge have conductivity values ranging from $350 \mu \mathrm{S} \mathrm{cm} \mathrm{cm}^{-1}$ to $650 \mu \mathrm{S} \mathrm{cm}^{-1}$ ). Low conductivity values calculated for diffuse source 1, located between points $\mathrm{A}$ and $\mathrm{B}$, indicate that these waters are likely flowing quickly through high-permeability, younger deposits and have less time for water-rock interaction. These results are supported by geologic 


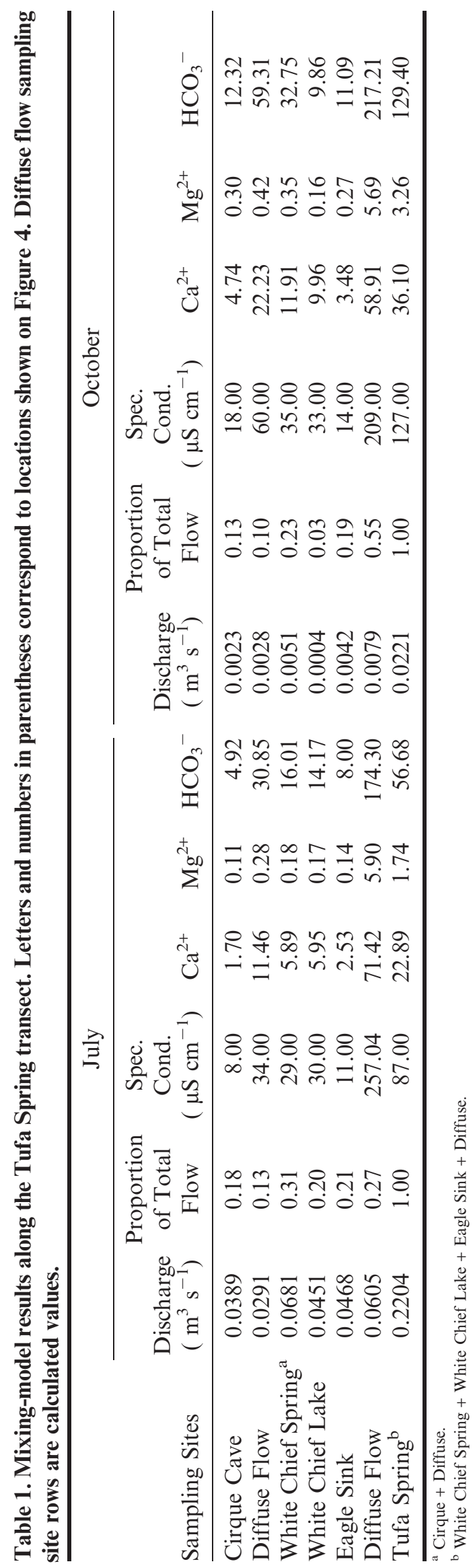

observations in these two areas. Diffuse source 2 water is derived from thick and poorly sorted glacial deposits lying directly on marble, while source 1 water flows through more recent, primarily granitic talus deposits. During the high-flow period, source 2 had generally higher calculated values than during low flow. Although we have minimal evidence in support of this, one explanation is that this water may be recharging via piston flow through the glacial deposits. Under this scenario, there may be a perched longer-term (annual) storage component in the system that is displaced as recent snowmelt water infiltrates and flushes it out. Then, during low-flow conditions, all the older water has been displaced and only more recent low-conductivity snowmelt waters remain and are recharging the system.

Big Spring responds differently to seasonal changes in the proportions of discharge derived from diffuse and concentrated recharge. Using only the difference between concentrated recharge and spring discharge to quantify diffuse recharge, the high-flow period in August appears to be dominated by diffuse flow, accounting for $72 \%$ of the discharge at Big Spring (Table 2). However, during September the percentage actually decreased to $52 \%$, which is surprising because the diffuse contribution would be expected to increase as rapid recharge, dominated by snowmelt, decreases throughout the dry season. Calculated values for specific conductance and chemical concentrations in diffuse source 5 in Figure 5 during August highflow conditions are lower, in some cases substantially, than might be expected for diffuse flow in this system, which are approximately the values found during September. For example, the specific conductivity was $144 \mu \mathrm{S} \mathrm{cm}^{-1}$ during high flow versus $217 \mu \mathrm{S} \mathrm{cm}^{-1}$ during low flow. This likely reflects the contributions of undetected and unmeasured sources of concentrated recharge into the system. In reality, the apparent decrease in the proportion of diffuse contribution to Big Spring between high flow and low flow is likely related to hidden sources of concentrated recharge, which violates the first assumption of the mixing model, that all unaccounted-for discharge is derived from diffuse sources. The lower specific conductivity and ion concentrations (Table 2) for August supports this, and subsequent field observations found that a series of small but unmeasured surface infeeders were likely still flowing during the August sampling, but were sinking upstream from our previously established sampling sites. If this was the case, then water was following unseen rapid flowpaths through and under landslide deposits before directly recharging the karst aquifer. During low-flow conditions in the Big Spring system, calculated specific conductance values for all three diffuse sources (3, 4, and 5) are relatively high, which is consistent with what is expected for water flowing slowly through overlying weathered unconsolidated materials and small fractures in the karst. Calculated values are also consistent with the specific conductivity of drip waters in Lilburn Cave (measured between 160 and $200 \mu \mathrm{S} \mathrm{cm}{ }^{-1}$ ), which are slightly higher 


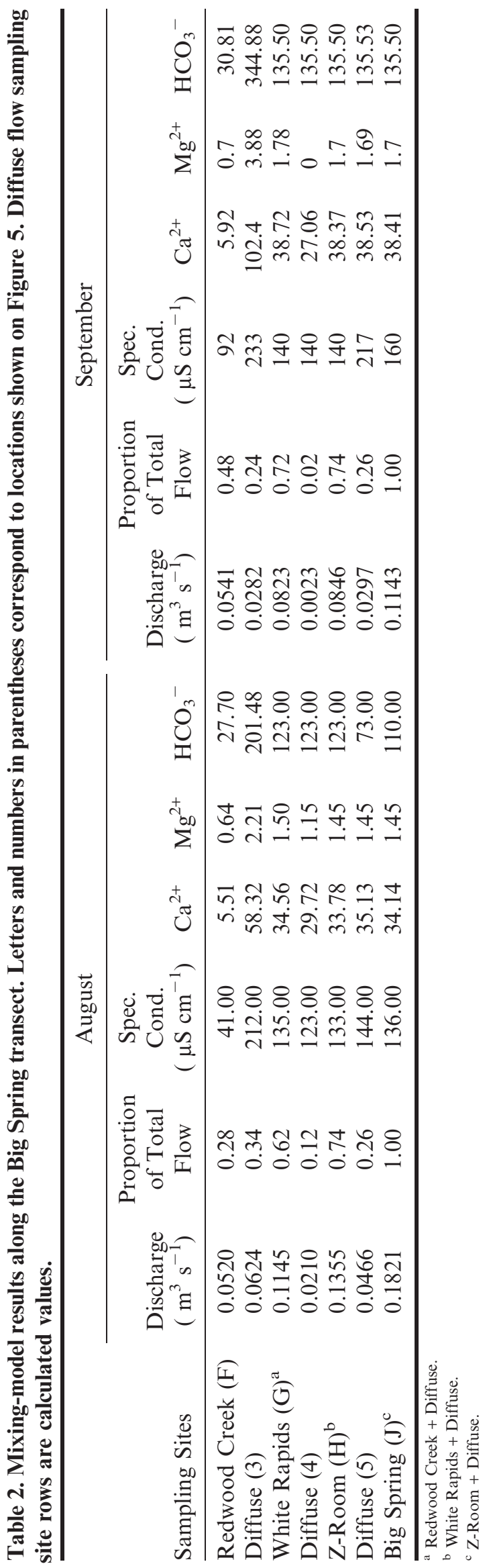

than the calculated high-flow, diffuse sources at points 4 and 5 in Figure 5 and Table 2.

In both the Tufa Spring and Big Spring systems, ion concentrations and total solute load increase as water moves from the headwater regions toward the springs. This is expected in groundwater systems due to water-rock interactions as water moves through the system. However, this research has shown that the reasons for increased solute loads may have little to do with the length of the primary conduit system and much more to do with inputs from diffuse sources: either small fractures and epikarst sources or overlying unconsolidated materials. In both systems, similar trends occur in ionic concentrations and specific conductance. Upstream tributaries that flow over or through non-carbonates have relatively low concentrations, while calculated diffuse inputs and locations sampled farther downstream have higher concentrations (Tables 1 and 2). While this is consistent with a model of downstream chemical evolution in which solute load increases as a function of residence time, system length, and rates of interactions with geologic materials, measured changes in water chemistry in the Big Spring system indicate that increased solute load is dominated by diffuse inputs along the main flow path rather than by dissolution of marble in the main stream conduit. In accessible portions of the main stream conduit where there is little observed diffuse or other input, specific conductance and ion concentrations stay relatively constant between sampling sites (Fig. 5), and the water is consistently undersaturated with respect to calcite. Only when additional water enters the system between the accessible cave and Big Spring does the chemistry change significantly.

Samples taken at Tufa Spring were also undersaturated with respect to calcite during both sampling periods. Because of the quick flow times in the aquifer, less than one day for storm pulses to move through the system, it is likely that measured changes in the ionic concentrations and specific conductance are due to seasonally variable contributions of diffuse flow into the system, rather than chemical evolution of waters along the main conduit, which is inaccessible.

\section{Conclusions}

Using simple methods and relatively easy to obtain field data, this study quantified the amounts of water derived from concentrated and diffuse recharge sources in the Big Spring and Tufa Spring karst systems. The proportion of flow derived from each type of recharge varies temporally, with concentrated recharge dominating during high flow and diffuse recharge dominating during baseflow conditions. Our data indicate that, although karst aquifers in Sequoia and Kings Canyon National Parks are complex systems with multiple flow paths, storage compartments, and residence times, many of them may be relatively easy 
to delineate and characterize because of their limited spatial extent and narrow geologic constraints.

This research highlights the importance of quantifying karstic aquifers in mountain hydrologic systems. Currently, karstic groundwater storage in the Kaweah River basin is not included in the conceptual model as described by Clow et al. (2003), nor is it included in any current water management plans or basin models. In addition, high baseflow discharge in the Kaweah River, relative to basin size and the number and size of porous media aquifers in the basin, does not follow the expected trend in which lesser amounts of these aquifer materials correlate with lower dry-season baseflow (Peterson et al. 2008). These findings highlight the importance of and need for modifying the existing conceptual model to include karst, even in settings where the aerial extent of karst may seem insignificant.

In most mountain basins, a substantial amount of water is stored in unconsolidated, porous deposits, as described by Clow et al. (2003). However, karst aquifers also have potentially substantial storage and can contribute significant amounts of groundwater to surface systems during seasonal dry periods, especially in systems such as the Kaweah that contain relatively few unconsolidated aquifer materials and numerous small karst aquifers. Based on our findings in two systems in SEKI, karst aquifers contribute significant amounts of water to the river system and should be included in conceptual models of mountain hydrology whenever karst is present. Karst aquifers are found elsewhere in the Sierra Nevada range and in many other mountain settings, yet because of the importance of snowmelt to annual river discharge, they are often ignored or underappreciated with respect to their contribution during the dry season. In addition, with future changes in climate predicted to result in increasing snowline elevations and less snowmelt discharge, the importance of seasonal or longer karstic storage in maintaining dry season flows will increase.

The susceptibility of any aquifer to contamination is a function of geologic materials, contaminant type, and the transport and flow regime. For a contaminant entering a system via diffuse flowpaths, it is likely that it will be temporally and spatially distributed, which means that it may be detected at the spring in low concentrations for long periods of time. However, if a contaminant enters an aquifer at a concentrated recharge site, it is more likely to be flushed quickly through the conduit system, bypassing most of the smaller fractures and pores, and behaving according to the model proposed by Loop and White (2001). Due to the variability in the retention time and amount of water stored in the two aquifers we studied, the residence time of a contaminant in each aquifer will be different. Higher storage in the diffuse component of the Big Spring system relative to the Tufa Spring system suggests that contaminants are likely to remain in storage for longer periods of time in the Big Spring system.
Although this means that a potential contaminant will be spatially and temporally dispersed as it moves through a porous media, sensitive organisms may be exposed to low concentrations for extended periods of time. In the Tufa Spring system, where rapid conduit flow and concentrated recharge dominate, potential contaminants will be flushed quickly through the system. However, if contaminants are deposited aerially and are stored in snowpack, they may also be released over the same time period as the snowmelt occurs.

The major differences in seasonal storage capacity between these two aquifers indicate that overlying unconsolidated materials must contribute substantially more to diffuse flow and storage on annual or shorter time scales than fracture storage does. However, in order to quantify these contributions, additional data are needed. Data presented here are not sufficient to separate matrix and fracture storage in the karst from storage in overlying unconsolidated deposits. Future study is needed to determine if there is a relationship between the proportion of diffuse flow and the amount, type, and maturity of available unconsolidated material. Although a relationship appears to exist in these two aquifers, where more mature unconsolidated materials correlate with larger and longer storage capacity, hydrogeochemical properties of some other karst springs in SEKI indicate much longer average residence times and larger karstic storage capacity. Characterizing recharge, hydrogeologic, and geochemical properties of these springs is the subject of current and future studies.

As SEKI begins planning for mitigation of potential anthropogenic impacts to the aquatic systems in the parks, including spills of toxins, use of fire-retardant or similar chemicals, and deposition of airborne contaminants in the basin, a better understanding of residence times and storage properties is required. Karst aquifers that are supplied by large amounts of water slowly flowing through unconsolidated material prior to entering a conduit system have greater potential for contaminant removal through natural attenuation, bioremediation, or biological uptake of nutrients such as nitrate and phosphate. This is because water moving through the unconsolidated material typically has a longer residence time, and thus, more time to interact and react with the surrounding materials. Water that enters the karst quickly, via larger conduits and fractures, typically has less potential for removal of contaminants from the water, increasing the likelihood that contaminants could leave the system at dangerous concentrations. However, the quick-flow systems also have the potential to flush the contamination through the system rapidly, minimizing potential long-term impacts. In either case, the results of this study contribute to improving our incomplete understanding of how marble aquifer systems in mountains function and will assist managers at SEKI and elsewhere in making scientifically informed and justifiable decisions.

Journal of Cave and Karst Studies, August 2012•195 


\section{ACKNOWLEDGEMENTS}

The authors would like to thank staff at Sequoia and Kings Canyon National Parks, especially Annie Esperanza and Joel Despain, for facilitating this project, the Cave Research Foundation for funding, Gabrielle Timmins, Shawn Thomas, Abby Tobin, Marek Cichanski, and Mason Bindl for lab and field assistance, anonymous reviewers for their comments, and Mario Parise and Robert Brinkman for organizing this special issue. This research was conducted under NPS permit \# SEKI-2010SCI-0041.

\section{REFERENCES}

Bakalowicz, M., 2005, Karst groundwater: a challenge for new resources: Hydrogeology Journal, v. 13, p. 148-160. doi:10.1007/s10040-0040402-9.

Clow, D.W., Schrott, L., Webb, R., Campbell, D.H., Torizzo, A., and Dornblaser, M., 2003, Ground water occurrence and contributions to streamflow in an alpine catchment, Colorado Front Range: Ground Water, v. 41, no. 7, p. 937-950. doi:10.1111/j.1745-6584.2003.tb02436.x.

Despain, J., 2006, Hydrochemistry in an Alpine Karst System, Sequoia and Kings Canyon National Parks, California [MS thesis]: Bowling Green, Western Kentucky University, 99 p.

Despain, J., and Tobin, B., 2010, Hidden Fire Hydrology Final Report: unpublished National Park Service Report, 10 p.

Engle, D.L., Sickman, J.O., Moore, C.M., Esperanza, A.M., Melack, J.M., and Keeley, J.E., 2008, Biogeochemical legacy of prescribed fire in giant sequoia-mixed conifer forest: a 16-year record of watershed balances: Journal of Geophysical Research, v. 113, G01014. doi: 10.1029/2006JG000391.

Ford, D., and Williams, P., 2007, Karst Hydrogeology and Geomorphology: Chichester, Wiley, 562 p.

Hafner, W.D., Solorzano, N.N., and Jaffe, D.A., 2007, Analysis of rainfall and fine aerosol data using clustered trajectory analysis for National Park sites in the Western US: Atmospheric Environment, v. 41, p. 3071-3081. doi:10.1016/j.atmosenv.2006.11.049.

Iqbal, M., and Krothe, N., 1995, Infiltration mechanisms related to agricultural waste transport through the soil mantle to karst aquifers in southern Indiana, USA: Journal of Hydrology, v. 164, p. 171-192. doi:10.1016/0022-1694(94)02573-T.

Lakey, B.L., and Krothe, N.C., 1996, Stable isotopic variation of storm discharge from a perennial karst spring, Indiana: Water Resources Research, v. 32, p. 721-731. doi:10.1029/95WR01951.

Landers, D.H., Simonich, S.M., Jaffe, D., Geiser, L., Campbell, D.H., Schwindt, A., Schreck, C., Kent, M., Hafner, W., Taylor, H.E., Hageman, K., Usenko, S., Ackerman, L., Schrlau, J., Rose, N., Blett,
T., and Erway, M.M., 2010, The Western Airborne Contaminant Assessment Project (WACAP): an interdisciplinary evaluation of the impacts of airborne contaminants in western U.S. national parks: Environmental Science and Technology, v. 44, p. 855-859. doi:10.1021/es901866e.

Lauritzen, S.-E., 2001, Marble stripe karst of the Scandinavian Caledonides: an end-member in the contact karst spectrum: Acta Carsologica, v. 30, no. 2, p. 47-79.

Loop, C.M., and White, W.B., 2001, A conceptual model for DNAPL transport in karst ground water basins: Ground Water, v. 39, no. 1, p. 119-127. doi:10.1111/j.1745-6584.2001.tb00357.x.

Musgrove, M., and Banner, J.L., 2004, Controls on the spatial and temporal variability of vadose dripwater geochemistry: Edwards Aquifer, Central Texas: Geochimica et Cosmochima Acta, v. 68, no. 5, p. 1007-1020. doi:10.1016/j.gca.2003.08.014.

Peterson, D.H., Stewart, I., and Murphy, F., 2008, Principal hydrological responses to climatic and geologic variability in the Sierra Nevada, California: San Francisco Estuary and Watershed Science, v. 6, no. 1, $21 \mathrm{p}$.

Rounds, S.A., 2006, Alkalinity and acid neutralizing capacity (version 3.0): U.S. Geological Survey Techniques of Water-Resources Investigations, book 9, chap. A6., section 6.6, http://water.usgs.gov/owq/ FieldManual/Chapter6/section6.6/, [accessed January 12, 2011].

Scanlon, B.R., Mace, R.E., Barrett, M.E., and Smith, B., 2003, Can we simulate regional groundwater flow in a karst system using equivalent porous media models? Case study, Barton Springs, Edwards Aquifer, USA: Journal of Hydrology, v. 276, p. 137-158. doi:10.1016/S00221694(03)00064-7.

Schwindt, A.R., Fournie, J.W., Landers, D.H., Schreck, C.B., and Kent, M.L., 2008, Mercury concentrations in salmonids from western U.S. national parks and relationships with age and macrophage aggregates: Environmental Science and Technology, v. 42, no. 4, p. 1365-1370. doi:10.1021/es $702337 \mathrm{~m}$.

Shelton, L.R., 1994, Field Guide for Collecting and Processing StreamWater Samples for the National Water-Quality Assessment Program: U.S. Geological Survey Open-File Report 94-455, 50 p.

Sisson, T.W., and Moore, J.G., 1994, Geologic map of the Giant Forest Quadrangle, Tulare County, California: U.S. Geological Survey, GQ$1751,1: 62,500,1$ sheet.

Slade, R.M., Jr., Dorsey, M.E., and Stewart, S.L., 1986, Hydrology and Water Quality of the Edwards Aquifer Associated with Barton Springs in the Austin Area, Texas: USGS Water Resources Investigations Report 86-4036, 117 p.

Tinsley, J.C., DesMarais, D.J., McCoy, G., Rogers, B.W., and Ulfeldt, S.R., 1981, Lilburn Cave's contribution to the natural history of Sequoia and Kings Canyon National Parks, California, USA, in Beck, B.F., ed., Proceedings of the Eighth International Congress of Speleology, volume 1, p. 287-290.

Tobin, B., and Doctor, D., 2009, Estimating karst conduit length using conductivity and discharge measurements in Lilburn Cave, Kings Canyon National Park, California, in White, W.B., ed., Proceedings of the 15th International Congress of Speleology, volume 3, p. 1702-1706. 